\title{
MUSEU DE GEOCIÊNCIAS DA USP
}

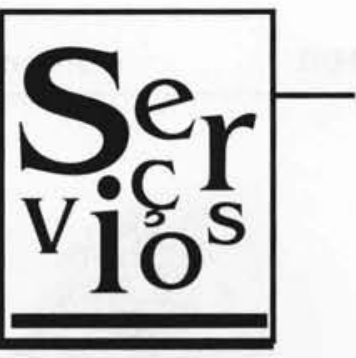

O Museu de Geociências do Instituto de Geociências (IG) da USP é detentor de um dos mais importantes acervos de minerais, minérios, gemas, rochas, fósseis e meteoritos do país.

Vem pres-

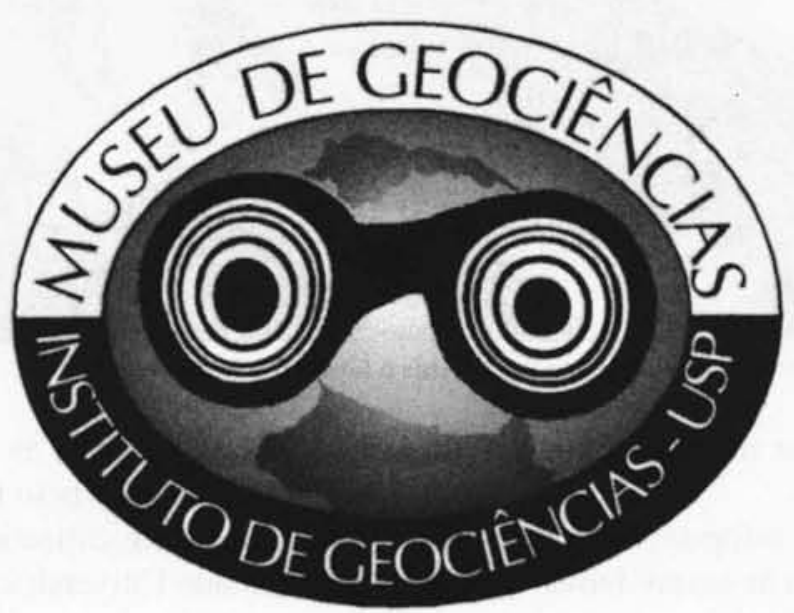

o aproveitamento da visita ao Museu.

O Museu também oferece orientação a colecionadores, alunos e professores na organização de coleções e feiras de ciência; identifica amostras de minerais e rochas, sendo que tando desde a sua fundação, em 1934, excelentes serviços à pesquisa científica da USP e à divulgação do conhecimento geocientífico junto a estudantes e professores de cursos secundários e universitários, comerciantes e industriais da área mineral, colecionadores e ao público em geral, tanto do Brasil quanto do exterior.

Recebe anualmente cerca de treze mil visitantes, sendo que $80 \%$ são de escolas secundárias. Essas visitas são preparadas antecipadamente, através de um roteiro específico feito com a orientação do Museu ao Professor encarregado do grupo visitante e abordam os assuntos estudados em sala de aula. Essa prática tem dado excelentes resultados: incentiva o Professor e aumenta algumas são encaminhadas ao laboratório de Raio X do Departamento de Mineralogia e Petrologia do IG/USP. Realiza palestras em colégios através de seus estagiários (alunos de Geologia). É procurado por editores de livros didáticos e agências de publicidade, com o fim de fotografarem seu acervo para ilustração.

O Museu de Geociências oferece cursos e palestras sobre os temas de sua abrangência. Além da exposição permanente de

\section{A AUTORA}

Maria Lúcia Rocha Campos

Diretora do Museu de Geociências da Universidade de São Paulo. 


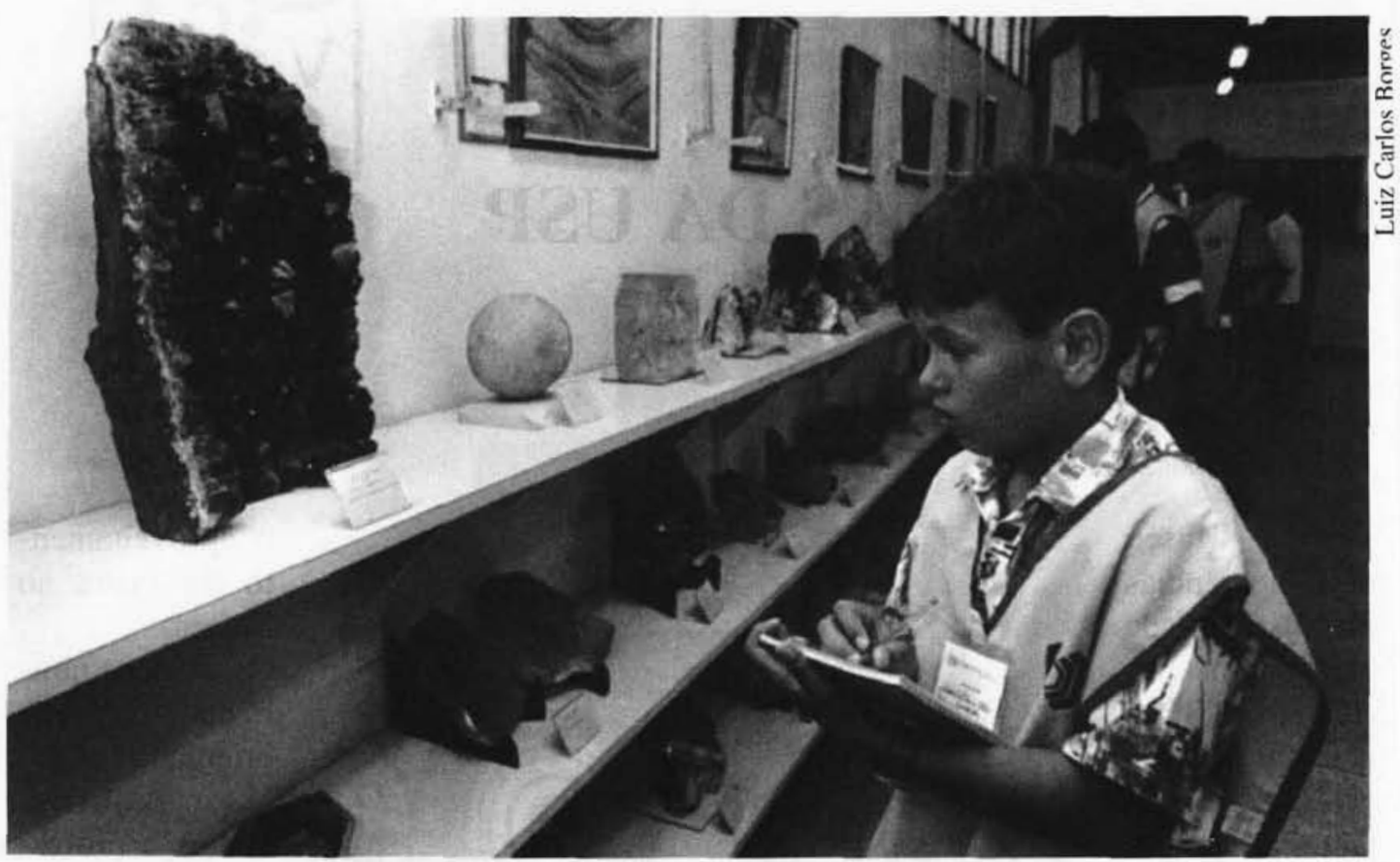

Estudante da cidade de Tambeiro, interior de São Paulo, visita o Museu de Geociências.

seu acervo, organiza mostras temáticas de assuntos específicos.

Para maiores informações entre em contato, de segundas às sextas-feiras, das $8 \mathrm{~h}$ às $12 \mathrm{~h}$ e das $13 \mathrm{~h} 30$ às $17 \mathrm{~h}$, pelo telefone (011) 8183952 ou pelo fax (011) 2104958. O Museu está localizado na Rua do Lago, 562 - Cidade Universitária - São Paulo - SP. 